DOI:10.18535/ijahm/v7i6.15

Impact Factor: 4.415

\title{
Review Article on VarnyaMahakashaya
}

\author{
${ }^{1}$ Dr. Rajni Rathore, ${ }^{2}$ Dr. Ramanand, ${ }^{3}$ Prof. Makhan Lal \\ 1P.G. Deptt. of Dravyaguna, State Ayurvedic College Lucknow \\ ${ }^{2}$ Lecturer of P.G. Dept. of Dravyaguna S.A.C. Lucknow. \\ ${ }^{3}$ Prof. and HOD of P.G. Dept.of Dravyaguna S.A.C. Lucknow.
}

\begin{abstract}
In C. Su. 4 there are 4 dasemani or mahakashaya of suffix ya they are balya, varnya, kanthya, hridya.Varnya word is explained as:

Varna- means colour andYa suffix denotes "wholesomeness" dividable two broad divisions-

Balya, varnya- Related to corporeal notions.

Kanthya, Hridya- Related to corporeal organs.

Those medicines or herbs which bring about and establish the original colour and complexion of an individual are called varnya. The great texts in Ayurveda, the charaksamhita, stated a group of ten medicinal plants known as varnyamahakashya that can be used to obtain glowing complexion. It includes SwetaChandan, Nagkesar, Padmaka, Ushira, Madhuka, Manjistha, Sariva, Payasya, Sita, Lata. These herb can be used individually combine and also externally or internally.

The present paper aims to review focuses on Charakoktavarnyamahakashaya as a natural and safe remedy for getting fairer skin and also for the detoxification of blood in raktapradosajvikaar.
\end{abstract}

Key words: VarnyaMahakashaya, complexion, Colour, Dasemani, Herbs.

\section{Introduction:}

Medicinal plants mentioned in samhita many centuries are recorded with complete understanding of various dimension reflected their usage. Several plants have been described and classified under different heads and along with therapeutic utility. Evolution of classification of the drugs, in order to identity and utilize the drugs, it classified on the basis of origin, qualities, action in a particular disease in all ayurvedic classical texts. The group based classification of drugs is well reported in Ayurveda since samhita period.

In original classics of ayurveda that is CharakSamhita and SushrutSamhita two separate chapters C. Su. 4 \& S. Su. 38 respectively, are enumerated based on rational grouping.

$>$ In C.S.Su-4, Fifty groups of dravyas based on their pharmacological classification with each group comprising of ten dravyas, under denomination of dashemani. Dashemani- itself suggests that it contains ten dravya. Each dashemanigana indicates the specific action on the body.

$>$ On critical observation, it was found that there is use of specific suffix in a group of mahakashaya, which enriches the properties of that particular mahakashaya.

$$
\begin{aligned}
& \text { नहिविस्तरस्य न चाप्यतिसंक्षेपोऽल्पबुद्धीनांसामर्थ्यायोपकल्पते , } \\
& \text { तस्मादनतिसंक्षेपेनातिविस्तरेणचोपदिष्टाः । } \\
& \text { एतावन्तोह्यलमल्पबुद्धीनांव्यवहाराय , } \\
& \text { बुद्धिमतां च स्वालक्षण्यानुमानयुक्तिकुशलानामनुक्तार्थज्ञानायेति।। }
\end{aligned}
$$


${ }^{1}$ Dr. RajniRathore, International Journal of Ayurvedic\& Herbal Medicine 7(6) Nov.-Dec. 2017 (3010-3023)

There is no limit of expansion, nor too much brevity can be sufficient for comprehending to those having low intelligence, hence (these) have been mentioned in neither too exhaustive nor too concise. These as such are enough for practice to the lowly intelligent and for the knowledge of hidden ideas to the intelligent and proficient in inference and rational on the basis of self definition.

Varnyamahakashaya is basically meant for the task of restoring the natural colour and complexion of the body.

\section{Aim of Study:}

The aim of this study was to critically evaluate the herbs mentioned in CharakoktaVarnyamahakashya as a natural and safe remedy for the maintenance of the complexion of the skin and also for thedetoxification of blood in raktapradosajvikaar.

To provide scope for further study.

\section{Material and method:}

\section{चन्दनतुंगपदमकोशीरमधुकमंजिष्ठासारिवापयस्यासितालताइतिदशेमानि वर्ण्यानि}

\section{भवन्ति ।I (च०सू० 4/8)}

Varnyamahakashaya contains ten drugs i.eChandan, Nagkeshar, Padmak, Ushir, Yastimadhu, Manjistha, Sariva, Payashya, Sita and Lata.

\section{CHANDAN}

Botanical name: Santalum album

Family:Santalaceae

Properties:

Rasa:Tikta, MadhuraGuna: Laghu, Ruksha

Vipaka:KatuVirya: Sita

Indications:Daha, Jvara, Kustha, Visarpa, Kandu, Trishna, Raktapitta.

Part used: Heart wood, Volatile oil

Dosage: powder 3-5gm, decoction 50-100ml

Important preparations: chandanadighrta, chandanaditaila, chandanasava etc.

Medicinal properties: Anti-inflamatory, Anti-septic, Astringent, Antispsmodic, Carminative, Diuretic, Hypotensive, Memory booster, Sedative.

- The Anti-septic quality of sandal wood benefits to treat rashes, acne, blackheads and other skin eruptions.Its germicidal quality inhibits the growth of bacteria and virus. It is also a natural astringent, especially for oily skin and also helps in toning up the skin.[8,9]

- When applied externally astringents cause coagulation of skin proteins and are used to protect the skin from acne, insect bitessuperficial cuts, or abrasions and allergies.

- Oil and paste very effective as anti-inflammatory agent.[10,11]Sandal wood has essential oil which is beneficial in case of nervous and circulatory system.[10]

- Sandal wood oil can be taking with milk or even water to reduce B.P. The paste also has same effect.[12]

- Oil of sandalwood is very good as an antiseptic. It is safe for both internal \& external application.

\section{Classical theraputic uses:}

\section{1.)चन्दनंदुर्गन्धहरदाहनिर्वापणलेपनानां ।। (च०सू० 25)}

Chandan is a good remedy for foetid smell, daha as a lepa. 
${ }^{1}$ Dr. RajniRathore, International Journal of Ayurvedic\& Herbal Medicine 7(6) Nov.-Dec. 2017 (3010-3023)

2.)Premeha- In sukrameha- The decoction of arjuna\&chandan is recommended. In manjisthameha, the decoction of manjistha\&chandan is recommended. (S.S.Ci 11)

3.)Chardi-Chandan is given along with the juice of Amalki. (C.S.Ci 20)

Sandal wood is one of natures most versatile and effective skin care treatments. Used as powder or as an oil extract, it is key ingredient used in the cosmetic industry to prepare perfume, soaps, powders, facial creams, and masks and also other Ayurvedic skin care products.

\section{TUNG(Naagkeshar)}

Botanical name: Mesuaferrea

Family: Guttiferae

\section{Properties:}

Rasa: Kasaya, TiktaGuna: Ruksa,Tiksna, Laghu

Vipaka: KatuVirya: Usna/Anusna

Indications:Raktarsas, Raktatisara, Raktapradara, Kustha, Visarpa, Jvara, Chardi, Vastivikara, Vatarakta, Sopha, Vataroga, Siroroga, Trsna, Kandu.

Part used: Stamens, leaf

Dosage: powder 1-3gm.

Important preparations: Kankarista, Caturjataka,EladiCurna, KesaradiKasayam

Medicinal properties: Anti-inflammatory, Antiseptic, Anti-pyretic, Anti-asthmatic, Antioxidant, Antitumor,Antimicrobial, Analgesic.

- It enhances the complexion. It leads to fragility transparency to the skin.

- The oil obtained from flowers stamen has antibacterial $[13,14] \&$ antifungal properties so it is used for skin infection such as itching, eczema and scabies also.

- The plant is famous for its anti- tumour activity[15] and anti-ulcer activity.[16]

- It reduces the toxicity of chemotherapy in the women suffering from breast cancer.[17]

Classical theraputic uses:

\section{1) दौर्गन्ध्यकुष्ठविसर्पकफपित्तविषापहम् । (भा 0प्र०)}

2) Raktarsas- Naga kesarcurna (1-3gm) shall be administrated orally along with butter and sugar. (C.S.Ci. 14/210)

3) Hikka- Naga kesarcurna is to orally with honey and sugar alongwith. (S.S.Ut.50/24)

4) Raktapradara-(S.N)

5) Svetapradara-(V.S \& Y.R)

6) Raktaatisara-(V.S)

Clinical Studies: In one of the clinical trials Naga kesaracurna $1 \mathrm{gm}$ thrice orally administrated to 20 female patients suffering from svetapradara. The results have showed significant improvement in all the cases treated.[18]

Research: It anti-convulsant and anti-inflammatory activities have been studied.

\section{PADMAKA}

Botanical name: Prunuscerassoides

Family: Rosaceae

Properties:

Rasa: Kashaya,TiktaGuna: Laghu, Snigdha

Vipaka: KatuVirya: Sita

Indications:Daha, Jvara, Kustha, Visarpa, Kandu, Trishna, Raktapitta.

Part used: Stem bark, Seeds

Dosage: powder 1-3gm 
${ }^{1}$ Dr. RajniRathore, International Journal of Ayurvedic\& Herbal Medicine 7(6) Nov.-Dec. 2017 (3010-3023)

Important preparations: Padmakadilepa,PadamakaTailam, MahaPadmakaTailam.

\section{Medicinal properties:}

- Prunuscerasoides is an Ayurvedic herb used for the treatment of several diseases. It is primarily used to treat back pain and skin disease like eczema \& wound, increasing the complexion and used as uterine tonic.

- The powder of the plant padmaka is applied in the form of paste

- in the treatment of skin disease, to improve the complexion of skin, to treat herpes.

- In Padamaka presence of six trace elements, including iron, zinc, and copper, in varying concentration in the extract of padamaka. These elements can play a role in the therapeutic utility of padamaka for curing eczema and wounds.

- It helps to relieve the symptoms of eczema such as itching,oozing of moisture, and dryness of the skin. It can also improve the healing of wounds. The antibacterial action produced by this herb can be beneficial in the management of skin infection.

- The bark of heart wood of padmaka is useful in the patient suffering from excessive sweating, burning sensation of the whole body and to treat fever.

\section{Classical theraputic uses:}

पद्यकंतुवरंतिक्तंवातह्हल्लघु । विसर्पदाहविस्फोटकुष्ठश्लेष्मास्रपितनुत् । (भा०प्र०)

1)Hikka-Svasa- Powder of stem bark of Padmaka is given orally with ghee (A.H.Ci.4)

2)Rakta pitta- Powders of Usira, Daruharidra (kaliyaka), Lodhra and Padamaka are useful in bleeding disorders(C.S.Ci 4).

\section{USHIR}

Botanical name: Vetiveriazizanoides

Family: Graminae

\section{Properties:}

Rasa:Tikta, MadhurGuna: Ruksa,Laghu

Vipaka: KatuVirya: Sita

Indications:Jvara, Daha,Rakta pitta,Chardi, Mutrakraccha, Trsna, Visarpa,Kustha.

Part used: Root

Dosage: powder 3-6gm; decoction 50-100ml; Infusion 25-50ml

Important preparations: Usirasava, Usiradicurna, UsiradiKvatha, Sadangpaniya, yograajguggul.

Medicinal properties: Cooling, expectorant, antispasmodic, antiasthmatic, anti- bacterial anti gout and diuretic activity.

- The most exiciting benefits of this plant is its ability to reduce the appearance of dark spots, and other marks on the skin, helping to create a more even skin tone.

- The root decoction has tonic properties and used to cure weakness. In high fever root decoction is given to reduce fever due to cooling nature of roots.

- The decoction of stem is given in urinary tract infections. [19] 
${ }^{1}$ Dr. RajniRathore, International Journal of Ayurvedic\& Herbal Medicine 7(6) Nov.-Dec. 2017 (3010-3023)

- It has strong antiseptic and anti inflammatory properties, hence it alleviates inflammation in the circulatory \& nervous system.[19]

\section{Classical therapeutic uses:}

1)लामज्जकोशीरंदाहत्वग्दोषस्वेदापनयनप्रलेपनानां ।। (च0सू० 25)

According to CharakLamajjak and Ushiraare the best remedy for burning sensation, skin disorder and to decrease sweating as lepa.

2) SwetaMasurika- The paste of usira is applied topically in case of prickly heat (V.D.)

3) Rakta pitta- Usira, Kokilaksa,Lodhra etc. are given in the form of decoction.(C.S.Ci.4)

4) Chardi- Usira and Dhanyakakalka is given with chanaka water (C.S.Ci 23)

\section{Contraindication:}

Vetiver has abortifacient, emmenagogue and uterotonic (include contraction and or greater tonicity of the uterus, uterotonics are used both to induce labour $\&$ to reduce postpartum haemorrhage) properties.So it is contraindicated in pregnancy.

It is not suitable for babies \& children under 12 years.

\section{MADHUKA}

Botanical name: Glycyrrhizaglabra

Family: Papilionateae

\section{Properties:}

Rasa:MadhurGuna: Guru, Snigdha

Vipaka: MadhurVirya: Sita

Indications: IBS, colitis, acidity, duodenal / peptic ulcer, prostate enlargement, allergy, healing substance, respiratory tract infection \& sore throat, cold.

Part used: Root

Dosage: powder 3-5gm

Important preparations: SataPakaMadhukataila, Madhuyastyaditaila, Yastyadichurna.

\section{Medicinal properties:}

- Liquorice root offers skin depigmenting, lightening, emollient, anti-acne, photo protection, antiaging, antimicrobial and antioxidant properties, all helpful for a healthy skin.[20]

- Glycyrrhizetic acid controls the secretion of melanin in skin and it has the effect of reducing dark pigmentation and making the complexion fairer.[21]

- Scientific research shows that when glycyrrhizin is broken down in the stomach is displays inflammatory and arthritic relieving effects similar to hydrocortisone and other corticosteroid hormones. 
${ }^{1}$ Dr. RajniRathore, International Journal of Ayurvedic\& Herbal Medicine 7(6) Nov.-Dec. 2017 (3010-3023)

- Glycyrrhizin is one of the best antiviral, effective against a variety of viruses, including those which cause influenza and common cold.

\section{Classical theraputic uses:}

1) मधुकंचक्षुष्यवृष्यकेश्यकण्ठयवर्ण्य विरंजनीयरोपणीयानां ।। (च०सू० 25)

According to charakYastimadhu is best remedy for eye disorder, impotence, hair disorder, throat disease, complexion of skin, and to make proper colouration of mutra and stool and also best wound healer.

2) Bhangadar- The wound should be applied with Madhukataila (S.S.Ci. 8)

3) Ardhavabhedaka-Yastimadhu is mixed with honey and used as Avapidananasya (S.S.Ut. 26)

4) Hrdroga- Paste of Yastimadhu and Katuki should be given with Sitajal. (C.S.Ci. 26)

\section{Contraindication:}

$>$ Anemia, high blood pressure, hypokalemia.

$>$ Large amount of licorice root taken over an extended time period can interfere with sodium/potassium balance \& cause fluid retention (oedema), high B.P., headache, dizziness \& heart problems, so herb should not be used more than 4-6 weeks.

Pregnancy due to retention of water.

\section{MANJISTHA}

Botanical name: Rubiacordifolia

Family: Rubiaceae

\section{Properties:}

Rasa: Madhur, TiktaGuna: Guru, Ruksha

Vipaka: KatuVirya: Usna

Indications:Jwara, Mootrakricha, Prameha, Kustha, Vrana, Netraroga.

Part used: Root

Dosage: powder 1-5gm, decoction 50-100ml.

Important preparations: Pindataila, MahaManjistadiKvath, Manjistaditaila, ManjistadiLepa, SinduradiTaila, Pancatiktaguggul.

Medicinal properties: Anti acne property, wound healing property, anti inflammatory activity, neuroprotection and antioxidant property.

Blood purifier- Useful in skin disease like hyperpigmentation, pimples scabies, eczema, skin allergies. It holds the reputation of a very good skin care herb as is used to make the complexion even and lighten dark spots.[25]

Blood Cleanser- clears off toxins like uric acid, very useful in gout.Tones up blood vessels,strength vascular system. 
${ }^{1}$ Dr. RajniRathore, International Journal of Ayurvedic\& Herbal Medicine 7(6) Nov.-Dec. 2017 (3010-3023)

This herb works very well both internally \& externally to promote skin glow \& lustre. It also helps to remove pimplesi.e anti-acne property[21,22], freckles, other discolouration\& promotes the healing of skin tissue damaged by injury or infection.

- Scientific study shows that it regulates blood pressure, blood vessel constriction \& helps prohibit blood clot formation.[24]

- Manjistha is used to treat raised uric acid, arthritis associated with gout, glandular swelling, skin disease such as pigmentation anomalies \&lecuoderma.[24]

- Manjistha can be used to treat irregular menstruation.[24]

- Wound and ulcers dressed with manjisthaghrita heal promptly \& get dried up \& well cleansed.[23]

- Manjistha used in all types of stone.[24]

\section{Theraputic uses:}

1) ManjisthaMeha- Manjistha and Chandanakasaya is useful.(S.S.Ci. 11/9)

2) Arsas- In bleeding piles ghee prepared with Manjistha and sigru should be given (S.S.Ci 6/9)

3) Kandabhagna-Manjistha and Madhuka are made in to paste using amladravyas and applied externally (V.M.)

Table: Therapeutic indication in skin disorder

\begin{tabular}{|c|c|c|c|}
\hline Indications & Formulations & Use & Reference \\
\hline Kustha, Kilasa,Prameha & Madhukaasava & Int. & C.Ci.-15/146 \\
\hline Vrana & VranaRopan & Ext. & S.Su.-37/23 \\
\hline Pitta samanvarga & Drugs & Int.-Ext. & S.Su.-40/8 \\
\hline Vrana & Vranaropantaila & Ext. & S.Ci.-2/73 \\
\hline $\begin{array}{c}\text { Vyanga, Neelika, } \\
\text { Vipadikahar }\end{array}$ & Ghritapakamardan & Ext & S.Ci.-26/38-41 \\
\hline Pittajroga & LodhradiAsthapanaBasti & Ext. & S.Ci.-38/55 \\
\hline Vyanga, Neelika & Manjisthaditaila & Ext. & A.H.U.-32/31 \\
\hline Sarvakustha & Bhritmanjisthadikwatha & Int. & S.Sh.-U-M-2 \\
\hline Vyanga & MukhaKantikarlepa & Ext. & S.Sh.-U-11/9 \\
\hline Vyanga & Vyangharlepa & Ext. & S.Sh.-U-11/12 \\
\hline Kustha & Bhritmanjisthadikwatha & Int. & Bh.P.-54/104-106 \\
\hline Kustha & Laghumanjisthadikwatha & Int. & Bh.P.-54/99-100 \\
\hline Kustha & Madhyammanjisthadikwatha & Int. & Bh.P.-54/101-103 \\
\hline
\end{tabular}

\section{SARIVA}

Botanical name: Hemidesmusindicus

Family: Asclepidaceae

\section{Properties:}

Rasa: Madhur, TiktaGuna: Guru, Snigdha

Vipaka: MadhurVirya: Sita

Indications:Jvara, kandu, prameha, kasa, svasa, pradar, aruchi, agnimandyaatisara.

Part used: Root

Dosage: powder 3-5gm, paste 5-10gm, infusion 50-100ml. 
${ }^{1}$ Dr. RajniRathore, International Journal of Ayurvedic\& Herbal Medicine 7(6) Nov.-Dec. 2017 (3010-3023)

Important preparations: Pindataila, Sariyadyasava, Mahatiktakaghrta, Pippalyadighrta, Amrtaghrta.

\section{Medicinal properties:}

Anti acne effect is tested against Propionibacterium acnes and Staphylococcus epidermidis which is responsible for acne vulgaris.[26]

It is one of the best detoxifying herb which helps in cleaning the body insideout. It helps in treating eczema, erysipels, psoriasis, and urticarial from heat and aggravated pitta. It cleans the blood, stop itching and reduce suppuration.

$>$ Hemidesmus cools the urinary tract, which effective alleviates the burning sensation during urination. The herb also useful in treating UTI \& kidney disorders.[27,28]

Effective as anti inflammatory[29], diuretic[27]\& vulnerary and syphilis.Hemidesmus is often combined with herb Picrorrhiza and used for Syphilis.

\section{Classical theraputic uses:}

1) अनन्तासांग्राहिकदीपनीय रक्तप्रशमनानाम् ।। (च०सू० 25)

According to CharakSariva is best drug for atisaar, loss of appetite and rakta disorder.

2)Vrana- Sariva root is claimed to be useful for cleansing all types of wound (V.M)

3)VisamaJvara- Decoction of patola, Sariva, Musta, Patha and Katuki is useful. (C.S.Ci. 3)

4)Kustha- Brhati, Usira, Patola, Sariva and Katuki is to be given for internal and external use.

\section{PAYASYA}

Botanical name: Ipomoea digitata

Family: Convolvulaceae

\section{Properties:}

Rasa: MadhurGuna: Guru, Snigdha

Vipaka: MadhurVirya: Sita

Part used: Kand

Dosage: powder 3-6gm

\section{Medicinal properties:}

Increase body weight.

$>$ Vasoconstrictor \&bronchoconstrictoreffect.

$>$ Liver protecting so can be used for treatment of enlarged liver \& spleen.

\section{9,10. DURVA}

Botanical name: Cynodondactylon

Family: Graminae

\section{Properties:}


${ }^{1}$ Dr. RajniRathore, International Journal of Ayurvedic\& Herbal Medicine 7(6) Nov.-Dec. 2017 (3010-3023)

Rasa:Kashya,MadhurGuna: Laghu

Vipaka: MadhurVirya: Sita

Indications: Wounds, Piles, Urticaria, Eczema, Indigestion, Menstruation problem.

Part used: panchang (whole plant)

Dosage: swarasa 10-20ml

Important preparations: Durvadikwatha, Durvaadhyataila, Durvaadhyaghrita.

\section{Medicinal properties:}

Skin disease- It is antiseptic and anti inflammatory in nature. The paste of doob grass juice and turmeric powder is good to cure skin problems such as skin rashes, itching, eczema, leprosy and scabies.

Blood cancer- it has good anticancer activity. 2TSF TDS

Classical theraputic uses:

\section{दूर्वास्वाद्वी हिमातिक्ताकषायाजीवनीजयेत् । कफपित्तास्रवीसर्पतृष्णादाहत्वगामयातन् ।। (कै० नि०)}

\section{Mode of action of VarnyaMahakashaya :}

When we use varnyamahakashya externally it acts on bhrajak pitta. Bhrajak pitta is responsible for the manifestation of our colour in the avbhasinitwacha. The colour and complexion is governed by the bhrajaka pitta.

When we use internally varnyamahakashya helps in detoxification of blood in raktapradosajvikaar and yakrit is the moolasthana for raktavahasrotas.

INTAKE OF AUSHADHA

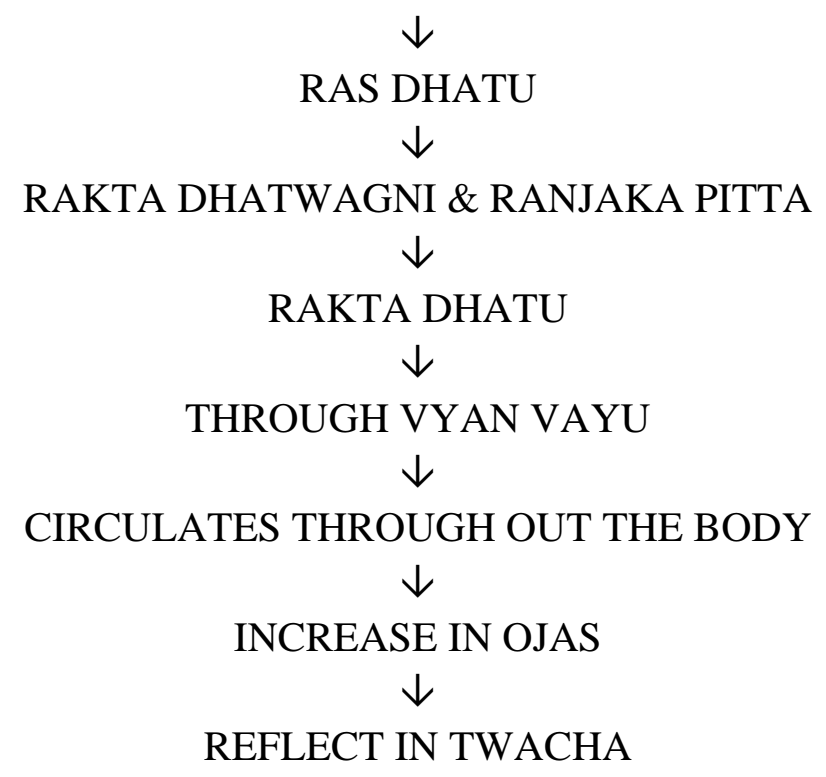

varnyamahakashyadravyas can be a drug of choice in case of skin disorders associate with liver dysfunction.

Pharmacodynamics of Varnyamahakashaya: 
${ }^{1}$ Dr. RajniRathore, International Journal of Ayurvedic\& Herbal Medicine 7(6) Nov.-Dec. 2017 (3010-3023)

\begin{tabular}{|c|c|c|c|c|}
\hline Mahakashaya & Ras & Guna & Vipaka & Virya \\
\hline Chandan & Tikta, Madhura & Laghu, Ruksha & Katu & Sita \\
\hline Tung & Kashaya, Tikta & Laghu, Ruksha,Tikshna & Katu & Anusna \\
\hline Padmaka & Kashaya, Tikta & Laghu, Snigdha & Katu & Sita \\
\hline Ushira & Tikta, Madhura & Laghu, Ruksha & Katu & Sita \\
\hline Madhuka & Madhura & Guru, Snigdha & Madhura & Sita \\
\hline Manjistha & Madhura, Tikta & Guru, Ruksha & Katu & Usna \\
\hline Sariva & Madhura, Tikta & Guru, Snigdha & Madhura & Sita \\
\hline Payasya & Madhura & Guru, Snigdha & Madhura & Sita \\
\hline Sita & Kashaya,Madhura & Laghu & Madhura & Sita \\
\hline Lata & Kashaya, Madhura & Laghu & Madhura & Sita \\
\hline
\end{tabular}

Drugs of varnyamahakashaya are of Madhura, Tikta, Kashaya rasa, and sitavirya. So these drugs chiefly will correct the vitiated pitta and also detoxify the blood hence act as colour and complexion promoters.

\section{Conclusion:}

These above ten drugs are natural cosmetics and detoxifying the blood. For this reason, it will be good for us.To explore the varnyamahakashya of charaksamhita to get a fairer skin in natural and safe way.

\section{Result:}

The aim of this study was to critically evaluate the herbs mentioned in varnyamahakashya for the maintenance of the complexion of the skin. Ayurvedic texts, journals and other research articles were reviewed. The great texts in Ayurveda, the Charaksamhita, stated a group of ten medicinal plants known as varnyamahakashya that can be used to obtain glowing complexion. It includes Swetachandan, Nagkesar, Padmaka, Ushira, Madhuka, Manjistha, Sariva,Payasya, Sita, Lata. These herb can be used individually combine and also externally or internally. The pharmacological properties of these herbs indicate that apart from the complexion promotion action, they have various medicinal properties. The most of them are prescribed for skin diseases and scientifically proved that they have anti-inflammatory, anti-bacterial, antiseptic, anti-ulcer, anti-tumour properties. Considering these facts it can be concluded that the use of varnyamahakashya is not only direct towards developing an attractive external appearance, but having various medicinal properties leads towards the achieving longevity with good health by maintaining skin complexion.

\section{References:}

1. ShastriKashinathPt, The CarakSamhita Of Agnivesa Revised By Carak And Drdhabala, Part -1, ChaukhambhaBharatiAcademy,Varanasi (U.P.), Edition-2009, Sutra Sthan- 4,25

2. Charak Samhita sutra sthana chapter $4^{\text {th }}$ and 25 thof Agnivesh redacted by Drdhabala edited by Prof. PriyaVrat Sharma published by ChaukhambaBharti Academy, Varanasi (U.P)

3. ShastriAmbikadutta, ShushrutaSamhita Of MaharshiSusruta Edited With Ayurveda-TattvaSandipika, Part- 1, ChaukhambhaSanskrit Sansthan, Varanasi (U.P.).

4. Bhav PrakashNighantu of Bhav Mishra by Dr. Krishna Chandra chunekar published by ChaukhambaBharti Academy, Varanasi (U.P)

5. Sharma P.V.DravyaGuna Vijnana-Vol-2, ChaukhambhaBharati Academy, Varanasi (U.P.)

6. DravyagunaVijanam part $2^{\text {nd }}$ of J.L.N.Sastry published by ChaukhambaBharti Academy, Varanasi (U.P.)

7. Gupta KavirajaAtrideva, Astangahrdayam of vagbhata edited by VaidayaYadunandanaUpadhayaya published by Chaukhambaprakashan, Varanasi (U.P.) 
${ }^{1}$ Dr. RajniRathore, International Journal of Ayurvedic\& Herbal Medicine 7(6) Nov.-Dec. 2017 (3010-3023)

8. Chourasia OP and Rao J. Tirumala; Anti bacterial Efficacy of Some Indian Essential Oils, Perfumery and Cosmetic, 1987, 68(Jahrgang, Nr.9/87), 564 -566.

9. Shankaranaryana KH et al; Antibacterial Activity of Sandal bark Tannins against Staphllococcusaureus, VanVigyan, 1986, 24(3\&4),120-121. 22. Kaur M et al; Skin cancer Chemopreventive

10. Sivaramakrishnan VR \& Shankaranarayana KH; Investigation on the insecticidal properties of plant extractives-I testing of new medicinal oils, HESP from spent sandalwood powder on insects, Science \& culture, 1990. 56(03), 124- 127.

11. Shankaranaryana KH \& Parathasarthi K; KESP: a new essential oil from the acid hydrolysis of spent sandalwood, Perfumer \& Flavorist, 1985, 10,60.

12. Albert C. Chibnall et al, Biochem J, 1981-1986, oct 1937.

13. Subramanyum RM. NV subbaroolate fatty acid composition of nahor (MesuaFerrae Linn) seed oil. J Richer Imagerie Med. 1977;(12):97-9.

14. Prashanth KV, Chauhan NS, Padh H, Rajani M. Search for antibacterial and anti fungal agents from selected indan medicinal plant. J Ethnopharmacol. 2006;(107):182-8.

15. Rana AYKM, Khanam JA, Asad-Ud-Daula M. Antineoplastic Screening of Some Medicinal Plants against Ehrlich Ascites Carcinoma in Mice. J Med Sci. 2004;(4):142-5.

16. Gopalakrishnan C, Shankarnarayanan D, Nazimudeen SK, Viswanathan S, Kameswaran L. Antiinflamatory and CNS depressant activities of xanthones from Calophylluminophyllum and Mesuaferrea. Ind J Pharmacol.1980;(12):181-91.

17. Saxena A, Dixit S, Aggarwal S, Seenu V, Prashad R, Bhushan SM, et al. An ayurvedic Herbal compound to reduce toxicity to Cancer chemotherapy: A randomized controlled trail. Indian J Med PaediatrOncol. 2008;(29):11-18.

18. Dr. J.L.N Sastry, DravyagunaVijana, Vol-2, forward by prof. K.C.Chunekar, ChaukhambaOrientalia 2005, pg-77.

19. V.Shubhra Devi et al. IJPSR 2010;1 (9): 120-124.

20. Last accessed on 2014 Mar 02]. Available from: http://www.konarkindex.com/index.php/mulethi .

21. Last accessed on 2014 Feb 20]. Available from: http://www.herbs-treat and taste.blogspot.in

22. Health Benefits of Mulethi or Liquorice. [Last accessed on 2014 Apr 18]. Available from:http://www.thehealthsite.com/

23. Vaibhav S, Lakshaman K. Tyrosinase enzyme inhibitory activity of selected Indian herbs. Int J Res Pharm Biomed Sci. 2012;3:977-82

24. http://www.ibiblio.org/pfaf/cgi-bin/arr_html?Rubia+cordifolia. Date of retrival: 23 sep 2007

25. Prabhajit K, Bikram S, Subodh K, Satwinderjeet K. In vitroevaluation on free radical scavenging activity of Rubiacordifolia. J Chin Clin Med. 2008;3:5.

26. G. Kumar, K. Jayaveera, C.K. Ashok, T. Bharathi, S.P. Umachigi, S. Vrushabendra Evaluation of antioxidant and antiacne properties of terpenoidal fraction of Hemidesmusindicus (Indian sarsaparilla) - Internet journal of aesthetic \& anti aging medicine. 20081 ( 1)

27. Navneet B. Gadge and Sunil S. Jalalpure, Natriuretic and saluretic effects of Hemidesmusindicus R. Br. root extracts in rats. Indian J Pharmacol. 2011 Nov-Dec; 43(6): 714-717.

28. Kotnis MS, Patel P, Menon SN, Sane RT. Renoprotective effect of Hemidesmusindicus, a herbal drug used in gentamicininduced renal toxicity. Nephrology (Carlton) 2004;9:142-52.

29. Joseph, P, Remington, Horatio and Wood, C. 1918. The Dispensatory of the United States of America. http://www.ibiblio.org/herbmed/eclectic/us disp/hemidesmus 
${ }^{1}$ Dr. RajniRathore, International Journal of Ayurvedic\& Herbal Medicine 7(6) Nov.-Dec. 2017 (3010-3023)

30. Abdullah S, Gobilik J and Chong KP. In vitro antimicrobial activity of Cynodondactylon (L) Pers (bermuda) against selected pathogens. Developments in Sustainable Chemical and Bioprocess Technology $2013: 227-237$.

31. Garg VK and Paliwal SK. Anti-Inflammatory activity of aqueous extract of Cynodondactylon. Int J Pharmacol 2011; 7(3): 370-375.

32. Krishnamoorthy M and Ashwini P. Anticancer activity of Cynodondactylon L extract on Ehrlich ascites carcinoma. J Environ Res Dev 2011; 5(3):551-557.

33. Saroja M and Annapoorani S. Antitumor activity of methanolic extract of Cynodondactylon leaves against Ehrlich ascites induced carcinoma in mice. J AdvSci Res 2012; 3(1):105-108.

34. Nayanatara AK, Akshatha A, Kottari S, Soofi AA, Rejeesh EP, Bhagyalakshmi K, Shetty S, Kini RD and Pai SR. Effect of Cynodondactylon extract on estrous cycle and reproductive organs in female Wistar rats. International Journal of Analytical, Pharmaceutical and Biomedical Sciences 2012; 1(3): 10- 15.

35. Nayanatara AK, Kottari S, Alva A, Soofi AA, Rejeesh EP, Bhagyalakshmi K, Shetty SB and Pai SR. Effect of aqueous extract of Cynodondactylon on reproductive hormones and reproductive organ weight of female Wistar rats. IJBPAS 2012; 1(8): 1065-1076.

36. Babu KS, Shaker IA, Kumaraswamy D, Saleembasha S and Sailaja I. Indigenous effect of Cynodondactylon in experimental induced ulcers and gastric secretions. Int Res J Pharm 2012; 3(5):301-304.

37. Patil MB, Jalalpure SS, Prakash SS and Kokate CK. Antiulcer properties of alcoholic extract of Cynodondactylon in Rats. International Society for Horticultural Science 2005; dio10.17660/actahortic.680.16.

38. Rai PK, Jaiswal D, Rai DK, Sharma B and Watal G. Antioxidant potential of oral feeding of Cynodondactylon extract on diabetes-induced oxidative stress. J Food Biochem 2010; 34: 78-92.

39. Singh SK, Kesari AN, Gupta RK, Jaiswal D and Watal G. Assessment of antidiabetic potential of Cynodondactylon extract in streptozotocin diabetic rats. J Ethnopharmacol 2007; 114(2): 174-179.

40. Jarald EE, Joshi SB and Jain DC. Antidiabetic activity of aqueous extract and non-polysaccharide fraction of Cynodondactylon Pers. Indian J ExpBiol 2008; 46(9): 660-667

41. Pal DK. Determination of brain biogenic amines in Cynodondactylon L. (Pers) and Cyperusrotundus L treated mice. Int J Pharm PharmSci 2009; 1: 190-197.

42. Pal D. Evaluation of CNS activities of aerial parts of CynodondactylonPers in mice. Drug Research 2008; 65(1): 37-43. 